\title{
NOTES ON TORTELLA (POTTIACEAE, BRYOPHYTA) IN THE CAUCASUS
}

\section{ЗАМЕТКИ О РОДЕ TORTELLA (РОТTIACЕAЕ, ВRYOРНYТА) НА КАВКАЗЕ \\ ELENA A. IGNATOVA ${ }^{1} \&$ HALina YA. DOROSHINA ${ }^{2}$}

\author{
Е.А. ИГНАТОВА ${ }^{1}$, Г.Я. ДОРОШИНА ${ }^{2}$
}

Abstract

Tortella nitida (Lindb.) Broth. is newly reported for the Russian part of the Caucasus region. Descriptions, illustrations, distinctions, ecology and distributional pattern are given for this species and for T. bambergeri (Schimp.) Broth. and T. flavovirens (Bruch) Broth. recently found in a coastal area of the Black Sea. The identity of T. brotheri (Lindb.) Broth. is discussed. Seven species of Tortella are currently known in the Russian part of the Caucasus: T. alpicola Dixon, T. bambergeri, T. flavovirens, T. fragilis (Hook. \& Wilson) Limpr., T. inclinata (R. Hedw.) Limpr., T. nitida and T. tortuosa (Hedw.) Limpr.. A key for identification of these species is provided.

Резюме

Tortella nitida (Lindb.) Broth. впервые найдена на Кавказе. Даны описания, иллюстрации, отличительные признаки, описана экология и распространение этого вида, а также недавно найденных на Черноморском побережье Кавказа T. bambergeri (Schimp.) Broth. и T. flavovirens (Bruch) Broth. Обсуждается таксономический статус T. brotheri (Lindb.) Broth. В настоящий момент на территории Российской части Кавказа известны семь видов рода Tortella: $T$. alpicola Dixon, T. bambergeri, T. flavovirens, T. fragilis (Hook. \& Wilson) Limpr., T. inclinata (R. Hedw.) Limpr., T. nitida и T. tortuosa (Hedw.) Limpr.; приводится ключ для их определения.

KEYWORDS: mosses, Tortella, taxonomy, Russia, Caucasus, phytogeography

Six species of the genus Tortella are listed for the Russian part of the Caucasus in the recent Check-list of mosses of East Europe and North Asia (Ignatov \& al., 2006); four of them, T. alpicola Dixon, T. bambergeri (Schimp.) Broth., T. flavovirens (Bruch) Broth. and T. inclinata (R. Hedw.) Limpr. were discovered in this territory in the last five years (Ignatova \& al., 2005; Ignatova \& Golub, 2006).

During the field work of the second author in the Sochi area of Krasnodar Territory one specimen of Tortella with strongly fragile leaves was collected; it was identified as Tortella nitida
(Lindb.) Broth., a species previously unknown in Russia. Here we provide a description and illustrations for this species, as well as for T. bambergeri and $T$. flavovirens, records for which, in Russia, have been unsufficiently discussed.

Tortella nitida (Lindb.) Broth., Nat. Pflanzenfam. I(3): 397. 1902. - Tortula nitida Lindb., Öfvers. Törh. Kongl. Svenska Vetensk.-Akad. 21: 252. 1864. - Fig. 1.

Plants medium-sized, in dense tufts, dull-green to yellowish-green above, brownish below, with shining costae on dorsal side. Stems 5-10(-20) $\mathrm{mm}$, with hyalodermis and weak to strong central

1 - Department of Geobotany, Biological Faculty, Moscow State University, Moscow 119991 Russia - Россия 119991, Москва, Московский университет, Биологический факультет, каф. геоботаники. E-mail: arctoa@list.ru.

2 - Komarov' Botanical Institute, Prof. Popova str., 2, Sankt-Petersburg, 197376 Russia - Россия 197376 Санкт-Петербург, ул. Проф. Попова, д. 2, Ботанический институт РАН им. В.Л. Комарова. E-mail: lebryo@mail.ru 
strand. Leaves strongly fragile, with most apices broken off, tightly incurved when dry, erectopatent to spreading when moist, hyaline basal part not exposed, oblong to linear-lanceolate, broadly acute, subobtuse or more narrowly acute to acuminate, slightly or moderately concave to nearly flat proximally, keeled distally, proximal parts without apices ca. 3-4 mm long, 0.4-0.7 mm wide; margins broadly incurved, often cucullate at apex, uneven distally, slightly papillose-crenulate, slightly undulate; lamina unistratose; upper and median laminal cells thin-walled, rounded-quadrate, rounded-hexagonal or transversely widened, 5-10 $\times 5-11 \mu \mathrm{m}$, obscure, covered by large bifid papillae; basal laminal cells hyaline, thin-walled, 50$75 \times 10-15 \mu \mathrm{m}$, transition to papillose median cells gradual, formed by smooth and slightly papillose chlorophyllose cells, smooth cells of transitional zone 15-50×10-12 $\mu \mathrm{m}$; costa strong, $75-120 \mu \mathrm{m}$ wide at base, gradually narrowing to the apex, excurrent into a short mucro, flat to slightly convex ventrally, on adaxial side covered by papillose quadrate cells except in the proximal $1 / 5-1 / 4$, on abaxial side covered by linear smooth cells on most of the length and by quadrate papillose cells in the distal $1 / 6-1 / 5$, in transverse section with $1(-2)$ rows of guide cells, two stereid bands, adaxial stereid band not extending to the distal part of leaf, adaxial epidermal layer differentiated. Dioicous. Sporophytes unknown from Russia. [Seta 17-18 mm. Urn 3-3.5 mm long. Peristome teeth ca. $0.5 \mathrm{~mm}$, erect to somewhat inclined, orangered, densely spiculose. Spores 9-11 $\mu \mathrm{m}$ (from Eckel, 1998)].

Tortella nitida was collected in a narrow gorge of the Agura River near Sochi, ca. $3 \mathrm{~km}$ from the the coast of the Black Sea, on soil in a crevice of a calcareous cliff, in shady forest. This species was not reported from the Caucasus region before, but we found one specimen previously collected in Georgia, Adzharia, Alexeenko and Woronow, 1902 (LE; identified by V.F. Brotherus as $T$. brotheri Lindb. ex Broth.); it was collected from rock walls of an old fort.

Tortella nitida is distributed mostly in Mediterranean and Atlantic areas of Europe, north to Great Britain, and in Central Europe, Macaronesia and North Africa; it is known from Israel, Turkey and was recently reported from Kazakhstan
(Allen, 1999). All records from North America are erroneous (Eckel, 1998).

Variability of $T$. nitida is described in detail by Eckel (1998). She stated, on the basis of the study of herbarium specimens from different regions of Europe, that the populations from coastal areas have leaves mostly broadly acute at apex and costa on the abaxial side entirely covered by smooth elongate cells, whereas collections from more elevated localities in the Alps have tendency to more narrowly acute to acuminate leaves with costa on the abaxial side covered by subquadrate papillose cells. Puche (2006) in Flora Briophítica Ibérica, Vol. 3, described the abaxial side of the costa of $T$. nitida as totally smooth. Bosanquet (2006) in a discussion on the differentiation of T. bambergeri mentioned that T. nitida, as well as $T$. fragilis, share with the former species the distal portion of abaxial side of costa being covered by papillose subquadrate cells. In both specimens from coastal area of the Black Sea, leaf shape is typical for the species, and papillose subquadrate surface cells on abaxial side of costa in the distal 1/5-1/4 are clearly seen, and this portion is even greater in immature intact leaves. Furthermore, this character was also observed in specimen from Spain in MO (Cano \#1061) and other European specimens in LE (see below).

Tortella nitida differs from all other Caucasian species of the genus by a very gradual transition between hyaline basal cells and chlorophyllose cells of the lamina; hyaline cells occupy a rather small proximal portion of the leaf and gradually change into smooth chlorophyllose cells, and then change to papillose and opaque roundedquadrate median cells; the hyaline border in the proximal part of leaf is not very distinct, consisting of 2-3 rows of longer cells, and sometimes it is even difficult to recognize this plant as Tortella. It can be confused with Trichostomum species, especially with T. brachydontium Bruch which is most similar in leaf shape. However, leaves of $T$. brachydontium are never fragile and totally lack a hyaline border in the proximal part of the leaf. Oxystegus tenuirostris (Hook. \& Tayl.) A.J.E. Sm., which is often placed in Trichostomum, has more or less fragile leaves, but they are more narrow, linear, gradually tapering to the apex and crisped when dry. Tortella nitida differs from T. tortuosa 

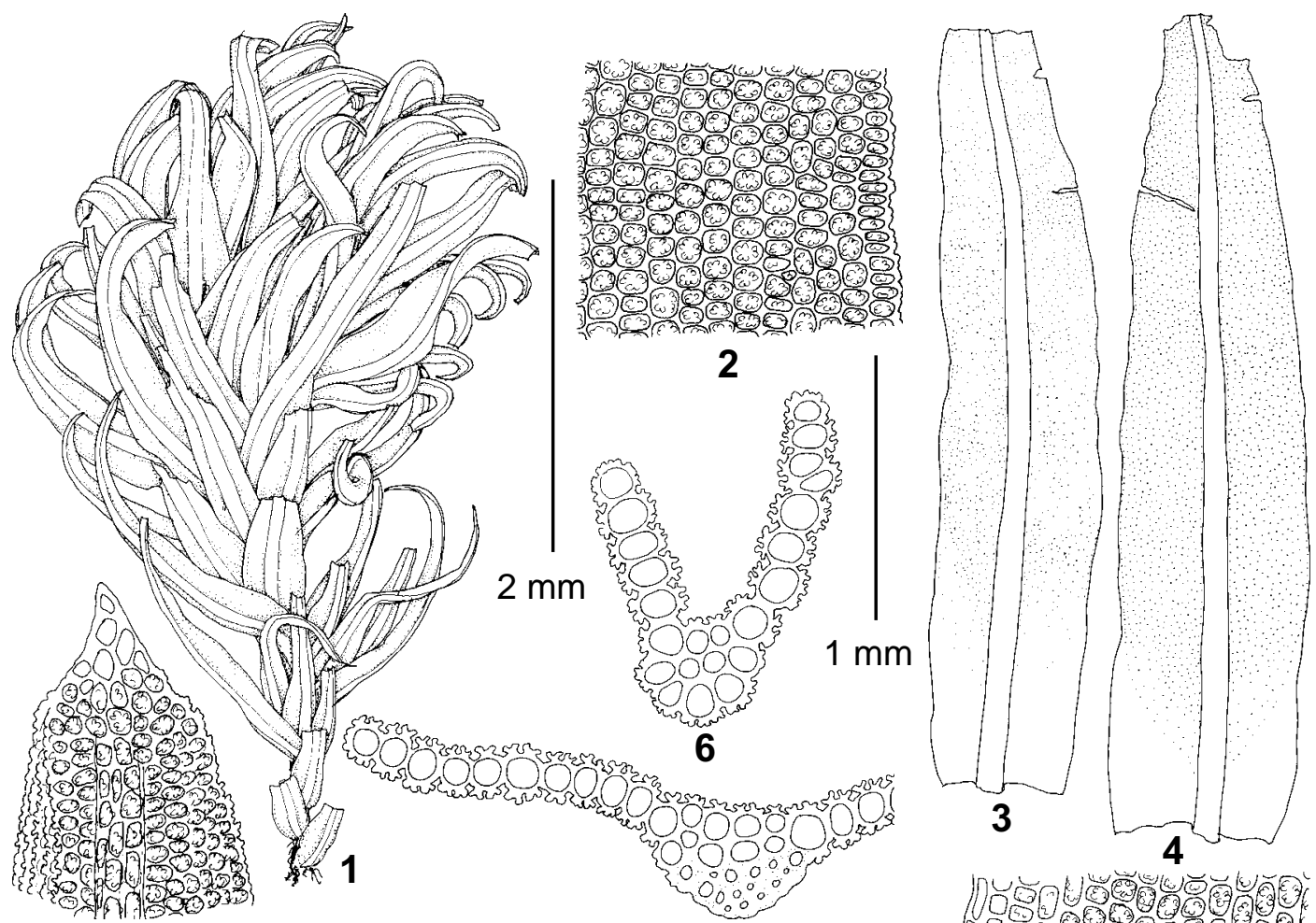

5

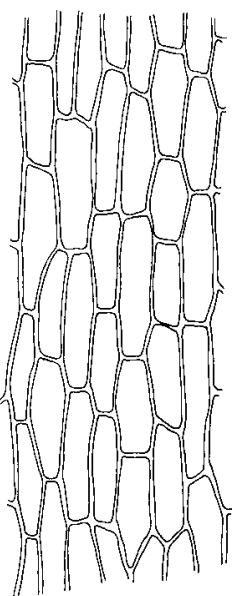

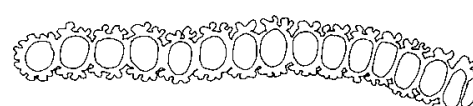

7
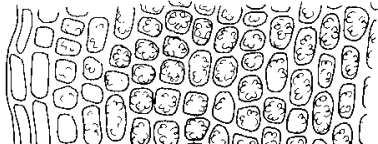

11003003

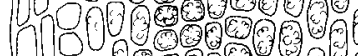

$50 \mu \mathrm{m}$

$100 \mu \mathrm{m}$
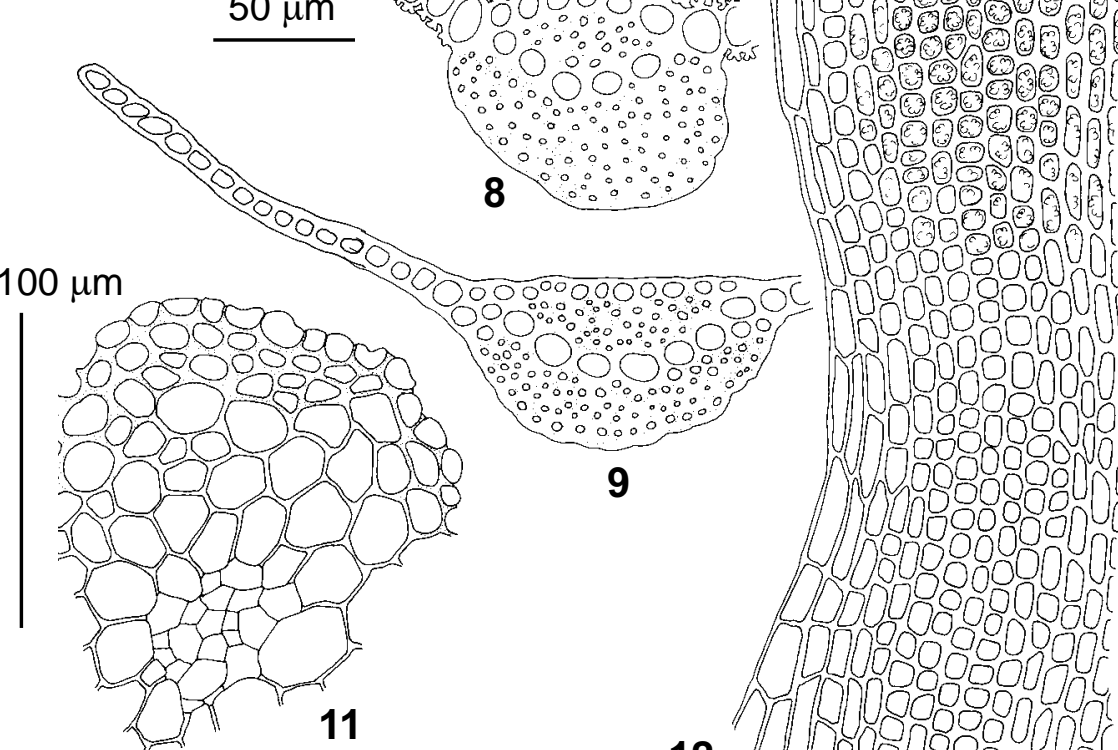

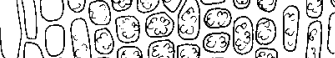

M 00000006

$8 \quad 0$
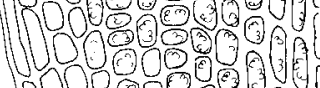

10030 तु है
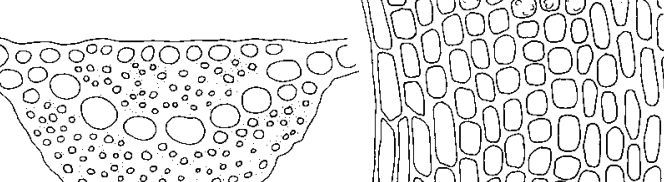

9
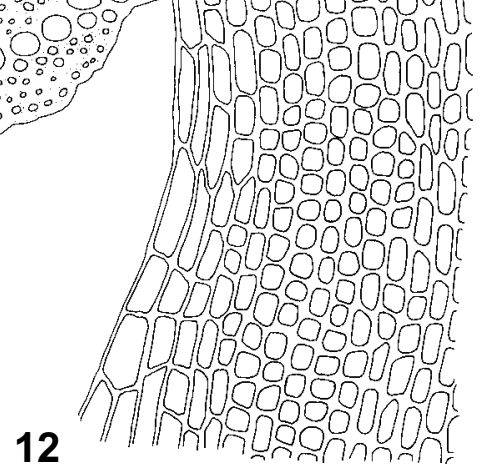

Fig. 1. Tortella nitida (Lindb.) Broth. (from Russia, Krasnodar Territory, Sochi, Ukrainskaya s.n., LE): 1 habit, dry; 2 - median laminal cells; 3, 4 - leaves; 5- upper laminal cells; 6-9 - leaf transverse sections; 10 - basal laminal cells; 11 - stem transverse section; 12 - transiton from basal to median laminal cells. Scale bars: $2 \mathrm{~mm}$ for 1 ; $1 \mathrm{~mm}$ for 3,$4 ; 100 \mathrm{~mm}$ for $2,5,10-12 ; 50 \mu \mathrm{m}$ for $6-9$. 
var. fragilifolia (Jur.) Limpr. by tightly incurved vs. crisped leaves, the presence of a central strand vs. its absence and the distal portion of the costa usually densely papillose on the abaxial side (better seen in intact immature leaves) vs. costa abaxially smooth throughout (sometimes only few papillae or projecting upper ends of surface cells are seen). Eckel (1998) mentioned that T. nitida usually forms hemispherical cushions like some Grimmia species, and this character is also helpful in its recognition.

Specimens examined: RUSSIA: Krasnodar Territory, Sochi area, Agura River gorge, $352 \mathrm{~m}$ alt., 18.X.2008, Ukrainskaya [Doroshina] s.n. (LE); GEORGIA: [Adzharia], prov. Batum, fort Gonia, 30.V.-12.VI.1902, Alexeenko \& Woronow s.n. (LE); SPAIN: Murcia, $200 \mathrm{~m}$ alt., Cano \#1061 (MO); FRANCE: Biarritz, 9.V.1908, Fleischer s.n. (LE); ITALY: Gorizia, 16.III.1880, Bottini s.n. (LE); CROATIA: Rovigna, 19.III.1924, Baumgartner s.n. (LE).

Tortella bambergeri (Schimp.) Broth., Nat. Pflanzenfam. 1(3): 397. 1902. - Trichostomum bambergeri Schimp., Syn. Musc. Eur. (ed. 2): 173. 1876. - Tortella tortuosa var. bambergeri (Schimp.) Düll, Bryol. Beitr. 4: 89. 1984. - Fig. 2.

Plants medium-sized, in dense to moderately loose tufts, light-green or yellowish-green above, light-brownish below, moderately tomentose in proximal part. Stems ca.10-20 mm, with hyalodermis and rather large central strand. Leaves crisped when dry, erect-spreading to spreading when wet, hyaline basal parts exposed, moderately to strongly fragile, with only few leaf apices intact, linear, gradually tapering to the apex, proximal parts of mature leaves without apices 3-4 mm long, 0.4-0.5(-0.6) mm wide, moderately concave, slightly undulate; margins weakly incurved, papillose-crenulate and slightly uneven distally; lamina unistratose, upper and median laminal cells thin-walled, rounded-quadrate or rounded-hexagonal, 7-10 $\mu \mathrm{m}$ wide, obscure, covered by large bifid papillae; basal laminal cells hyaline, thinwalled, $50-80 \times 9-12 \mu \mathrm{m}$, transition to papillose median cells abrupt, V-shaped; costa strong, 70$100 \mu \mathrm{m}$ wide at base, gradually narrowing distally, excurrent into short, epapillose, slightly denticulate mucro, flat to slightly convex ventrally, on adaxial side covered by papillose quadrate cells except in the proximal $1 / 5-1 / 4$, on abaxial side covered by linear smooth cells on most of the length and by quadrate papillose cells in the distal $1 / 5-1 / 4$, in transverse section with one row of guide cells, two stereid bands, adaxial stereid band not extending to the distal part of leaf, adaxial epidermal layer differentiated. Dioicous. Sporophytes unknown from Russia. [Seta 8.5-10 mm. Urn 1.5-1.7 mm long, cylindrical, slightly asymmetric. Peristome teeth ca. $350 \mu \mathrm{m}$ long, papillose, straight or twisted half a turn. Spores 10-12 $\mu \mathrm{m}$ (from Bosanquet, 2006)].

Tortella bambergeri was found in three areas in the Krasnodar Territory. It was collected in the projected Utrish Reserve, between Anapa and Novorossijsk; this area is characterized by a submediterranean climate with rainy winters and hot dry summers, bedrocks are mostly carbonate, and the vegetation in lower altitudinal belt is composed of arid sub-mediterranean forests of Juniperus oxycedrus, J. excelsa, Pistacia mutica, Quercus pubescens, etc., and in the upper belt, broad-leaved forests with sparse herbaceous cover dominate. The species is locally not rare, it occurs almost throughout the territory from about sea level to ca. $300 \mathrm{~m}$ a.s.1., mostly on mesic to xeric rocks, occasionally on limestone gravel, on old brick hedge, at bases of Quercus and Juniperus trunks, from open stations to shady broad-leaved forests. Tortella bambergeri was first identified as T. tortuosa (Hedw.) Limpr. (Ignatova et al., 2005), but further study of these collections and comparison with specimens of $T$. bambergeri from Austria showed that all records of $T$. tortuosa from Utrish belong to T. bambergeri (Ignatova \& Golub, 2006). The second locality was discovered in the course of the revision of collections in LE: Anapa District, Kryglaya Shchel'. And the third locality is in the Apsheronsky Districts, near Mezmai, ca. $70 \mathrm{~km}$ from the Black Sea coast; the species was collected there by the second author, on basic rock in shady forest in a relatively mesic environment.

The species was also identified in collections from Karachaevo-Cherkessia and Dagestan. According to labels, it grew on soil in forest as well as on sandstone rocks.

Tortella bambergeri was described from Austrian Alps (Tirol) and untill recently its was reported only from Central Europe. Bosanquet (2006) 


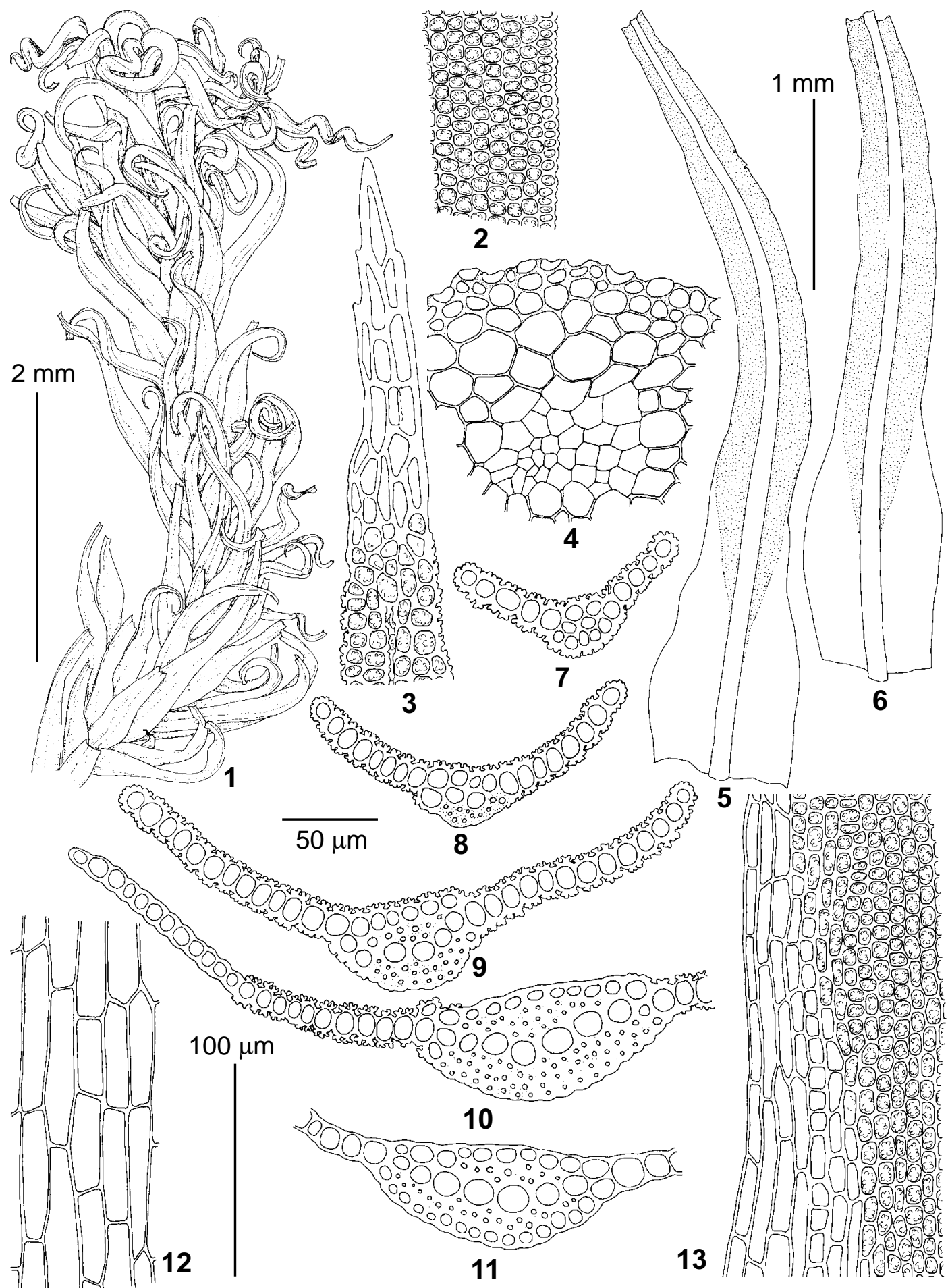

Fig. 2. Tortella bambergeri (Schimp.) Broth. (from Russia, Krasnodar Territory, Anapa District, Maly Utrish Ignatov \& Ignatova \#05-359, MW): 1 - habit, dry; 2 - median laminal cells; 3 - upper laminal cells; 4 - stem transverse section; 5-6 - leaves; 7-11 - leaf transverse sections; 12 - basal laminal cells; 13 - transiton from basal to median laminal cells. Scale bars: $2 \mathrm{~mm}$ for $1 ; 1 \mathrm{~mm}$ for 5-6; $100 \mathrm{~mm}$ for 2-4, 12-13; $50 \mu \mathrm{m}$ for 7-11. 
reported a considerable number of localities of the species in Great Britain and Ireland based on his own new collections as well as revision of herbarium specimens prevously identified mostly as T. tortuosa var. fragilifolia. After that, T. bambergeri was discovered in several localities in the Iberian Peninsula (Brugués et al., 2009). The distribution of $T$. bambergeri seems to be still incompletely known because some authors did not recognize it as a separate species and placed it within the variability of T. tortuosa (Bosanquet, 2006). The species was never reported from North America, but the description of the variability of $T$. tortuosa var. fragilifolia in North American material (Eckel, 1998, 2007) allows one to suspect that $T$. bambergeri may occur there. Main diagnostic characters separating T. bambergeri from fragile forms of T. tortuosa are the presence of central strand and abaxial side of costa covered by papillose subquadrate cells in its distal portion. Both characters are mentioned as occasionally present in some North American collections of T. tortuosa var. fragilifolia and are illustrated by Eckel (1998, 2007).

Our study of herbarium materials of T. tortuosa from Caucasus in MW and MHA did not reveal any other collections with a central strand or dorsally papillose costa. The latter character was never taken into account in Russian handbooks of mosses, but the presence of a central strand was mentioned for T. brotheri Lindb. ex Broth. by Savicz-Lyubitskaya \& Smirnova (1970). However, the protologue of the species did not describe a stem transverse section (Brotherus, 1892). Collections of Brotherus in $\mathrm{H}$ were not available for our study (being loaned), but we studied two syntypes of Mollia brotheri in LE. It turns out that they belong to different species. One of them, "Imeretia, Utzeri pr. fl. Rion, V.F. Brotherus, 7.VII.1871" is, to our mind, just a slender form of T. tortuosa and well agrees with the diagnosis of Mollia brotheri that differentiates it from M. tortuosa in smaller size of plants, lighter colour and shiny dorsal side of costa. Another syntype, "Ossetia, ad fl. Didi Liachva, A.H. \& V.F. Brotherus, 17.VII.1881" has a well-developed central strand, fragile leaves and dorsally papillose distal portion of costa, thus agreeing with T. bambergeri in all important details. This may explain why the pres- ence of a central strand was reported and illustrated in T. brotheri (Savicz-Lyubitskaya \& Smirnova, 1970). Before the formal lectotypification, Tortella brotheri seems to be conspecific with $T$. tortuosa, as the smooth and shiny costa mentioned in the protologue contradicts characters established for T. bambergeri.

Selected specimens examined: RUSSIA: Krasnodar Territory: Anapa District, projected Utrish Reserve, Ignatov \& Ignatova \#05-350 (MW); Anapa District, Kruglaya Shchel', 13.IX.1959 Abramova \& Abramov s.n. (LE); Apsheronsky District, Mezmai settlement surroundings, 8.VIII.2003, Ukrainskaya \#13807 (LE); Karachaevo-Cherkessia: Bermamyt Mt., 14.VIII.1993 Ukrainskaya s.n. (LE); Daut River Gorge, 5.VIII.1993 Ukrainskaya s.n. (LE); Dagestan: Kaitagsky District, between Madzhalis and Zil'bagi settlements along road to Urkarakh, 8.VII.1961 Bobrov s.n. (LE). SOUTH OSSETIA, ad fl. Didi Liachva, 17.VII.1881, A.H. \& V.F. Brotherus s.n. (LE).

Tortella flavovirens (Bruch) Broth., Nat. Pflanzenfam. I (3): 397. 1902. - Trichostomum flavovirens Bruch, Flora 12: 404, pl. 2. 1829. - Fig. 3.

Plants medium-sized, in dense tufts, yellowishgreen above, light-brownish below. Stems 5-15 $\mathrm{mm}$, with hyalodermis and weak central strand, forked, with sparse rhizhoids in leaf axils. Leaves contorted when dry, erecto-patent to spreading when moist, hyaline basal parts not exposed, not fragile, ovate-lanceolate, acute or subobtuse, moderately concave to nearly flat proximally, keeled-concave distally, 2-3 mm long, 0.4-0.6 $\mathrm{mm}$ wide; margins erect or broadly incurved, often cuculate at apex, slightly papillose-crenulate; lamina unistratose; upper and median laminal cells thin-walled, rounded-quadrate or rounded-hexagonal, 8-12 $\mu$ m wide, obscure, covered by bifid papillae; basal laminal cells hyaline, lax, thin-walled, 40-70×10-18 $\mu \mathrm{m}$, transition to papillose median cells mostly abrupt; costa strong, 60-100 $\mu \mathrm{m}$ wide at base, gradually narrowing to the apex, excurrent into short mucro, flat to slightly convex ventrally, on adaxial side covered by papillose quadrate cells except in the proximal 1/5-1/4, on abaxial side covered by linear smooth cells, in transverse section with one row of guide cells, two stereid bands, adaxial stereid band not extending to the distal part of leaf, adaxial epidermal layer differentiated. Dioicous. Sporophytes unknown from Russia. [Seta 

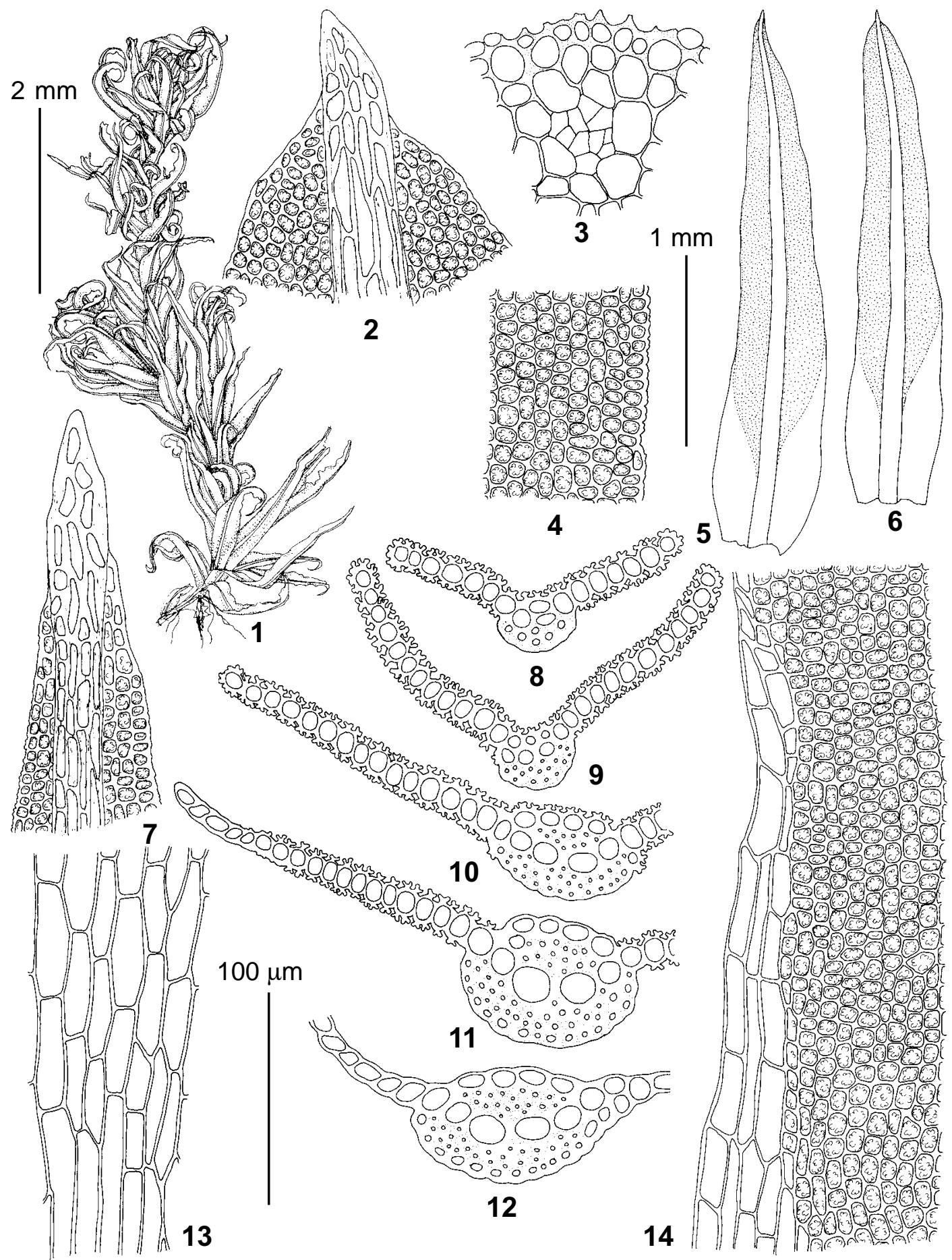

Fig. 3. Tortella flavovirens (Bruch) Broth. (from Russia, Krasnodar Territory, Anapa District, Maly Utrish Ignatov \& Ignatova \#05-584, MHA): 1 - habit, dry; 2, 7 - upper laminal cells; 3 - stem transverse section; 4 median laminal cells; 5-6 - leaves; 8-12 - leaf transverse sections; 13 - basal laminal cells; 14 - transiton from basal to median laminal cells. Scale bars: $2 \mathrm{~mm}$ for $1 ; 1 \mathrm{~mm}$ for 5-6; $100 \mathrm{~mm}$ for 2-4, 7-14. 
red, 11-13 mm. Urn 1.8-2.2 mm long. Peristome teeth ca. $0.5 \mathrm{~mm}$, straight to somewhat inclined or slightly twisted. Spores $10-14 \mu \mathrm{m}$ (from Eckel, 1998)] .

Tortella flavovirens was collected on the Black Sea coast between Anapa and Novorossijsk, in the territory of projected Utrish Reserve, just behind gravely beach of the sea, on the shores of two small somewhat salty lakes, on soil among Carex and Juncus spp. This habitat is quite appropriate for the species which is known as a salt-tolerant plant, usually growing on coastal beaches in saltwater spray (Eckel, 1998). In Europe it is confined to the Mediterranean and Atlantic coasts, north to Great Britain; it is also known from Macaronesia, North Africa, SW Asia, New Zealand and southeastern North America.

In leaf shape $T$. flavovirens resembles $T$. inclinata; both species have acute to subobtuse concave leaves and abruptly delimited hyaline proximal cells; however, they are easily differentiated by the costa covered on the adaxial side by papillose subquadrate cells in the former species vs. smooth linear cells in the latter one, in leaf transverse section with a differentiated adaxial epidermal layer vs. a non-differentiated one with an exposed adaxial stereid band. Furthermore, T. flavovirens usually has a central strand while $T$. inclinata lacks it. Other species of Tortella with a central strand (T. bambergeri, T. nitida, T. alpicola) have strongly fragile leaves, contrary to T. flavovirens.

Specimen examined: RUSSIA: Krasnodar Territory, Anapa Distr., projected Utrish Reserve, Ignatov \& Ignatova \#05-584 (MHA).

Among other species of the genus, only T. tortuosa is common in the Caucasus; it is frequent in a wide range of habitats above tree line and sparse in the forest belt. Tortella tortuosa var. fragilifolia is very rare, few known specimens of this variety were collected at high altitudes. Tortella fragilis was reported as a rare species in alpine belt from Teberda Reserve in Karachsevo-Cherkessia (Ignatova et al., 2008) and from Kabardino-Balkaria (Kharzinov et al., 2004), but it is not known from the Caucasian Reserve (Akatova, 2002).

Tortella alpicola and T. inclinata were only recently discovered in the Caucasus, and both are known just by a single record. Tortella alpi- cola was collected in Karachaevo-Cherkessia, Teberda Reserve, at ca. $1450 \mathrm{~m}$ a.s.1., in crevices of dry cliffs near waterfall (Ignatova et al., 2008). Tortella inclinata was reported from Mostovkoj District of Krasnodar Territory, near Psebaj settlement, on steep slope of Malaya Laba Gorge, on gypsum outcrops (Ignatova \& Golub, 2006).

\section{KEY FOR IDENTIFICATION OF SPECIES OF TORTELLA IN THE CAUCASUS}

1. Leaves fragile, most apices of mature leaves broken off .................................................. 2

- Leaves not fragile, most leaf apices intact 6

2. Caducous leaf tips segmented, consisting of several units; plants small, stems 0.5-1(1.5) $\mathrm{cm}$, central strand present; leaves to $2 \mathrm{~mm}$ long T. alpicola

- Caducous leaf tips not segmented; plants usually larger, central strand present or absent; leaves usually longer than $2 \mathrm{~mm}$.............. 3

3. Lamina bistratose distally; leaves slightly curved with usually straight upper part; marginal cells often extending above half of leaf length ........................................ T. fragilis

- Lamina unistratose throughout; leaves crisped, contorted or tightly incured; marginal cells often extending above half of leaf length 4

4. Abaxial side of costa covered by smooth elongate cells throughout; central strand absent

T. tortuosa var. fragilifolia

- Abaxial side of costa in distal portion covered by papillose subquadrate cells; central strand present 5

5. Leaves tightly incurved, not crisped when dry, oblong to linear-lanceolate, broadly acute and often cucullate at apex; transition between hyline basal laminal cells and papillose median cells very gradual .................. T. nitida

- Leaves contorted or crisped when dry, linear, narrowly acute or acuminate, not cucullate; transition between hyline basal laminal cells and papillose median cells abrupt

T. bambergeri

6(1).Leaves linear, to $7 \mathrm{~mm}$ long, acuminate, not cucullate at apex .... T. tortuosa var. tortuosa

- Leaves oblong-lanceolate to elliptical, to 3.5 mm long, broadly acute to obtuse, often cucullate at apex

7. Autoicous, sporophytes frequent; stems to 5 
mm long; leaves crouded, shoots rosulate; transition between hyaline basal laminal cells and papillose median cells gradual [T. humilis (Hedw.) Jenn.]

- Dioicous, sporophytes rare; stems longer than $5 \mathrm{~mm}$, evenly foliated; transition between hyaline basal laminal cells and papillose median cells abrupt 8

8. Central strand absent; adaxial side of costa covered by elongate smooth cells throughout T. inclinata

- Central strand usually present; adaxial side of costa covered by papillose subquadrate cells in distal 3/4 of leaf . T. flavovirens

\section{ACKNOWLEDGEMENTS}

Authors are greatly indebted to Heribert Köckinger for duplicates of Tortella bambergeri and to Patricia Eckel for valuable comments and improving of English. The work was partially supported by RFBR \# 07-04-00013 and Scientific School Program HШ-4243-2008.4.

\section{LITERATURE CITED}

[AKATOVA, T.V.] АКАТОВА Т.В. 2002. Листостебельные мхи Кавказского заповедника (Западный Кавказ, Россия). - [Moss flora of the Caucasian Nature Reserve (Western Caucasus, Russia)] Arctoa 11: 179-204.

ALLEN, B. 1999. Data on species of Kazakhstan, Tadjikistan, Uzbekistan, Kyrgyzstan, Turkmenistan presented in MO database: http://mobot.mobot.org/cgi-bin/search_vast.

BOSANQUET, S.D. 2006. Tortella bambergeri (Schimp.) Broth. in the British Isles. - J. Bryol. 28: 5-10.

BROTHERUS, V.F. 1892. Enumeratio muscorum Caucasi. Acta Soc. Sci. Fenn. 19(12): 1-170.

BRUGUÉS, M., F. PUCHE \& K.CESÓN 2009. Tortella bambergeri (Pottiaceae) in the Iberian Peninsula, with an updated key to Iberian Tortella. - Bryologist 112(1): 164-172.

ECKEL, P.M. 1998. Re-evaluation of Tortella (Musci, Pottiaceae) in conterminous U.S.A. and Canada with a treatment of the European species Tortella nitida. - Bull. Buffalo Soc. of Natural Sciences 36: 117-191.
ECKEL, P.M. 2007. Tortella. - In: Flora of North America. Vol. 27. Mosses, part. 1. New York, Oxford, Oxford Univ. Press: 498-511.

IGNATOV M.S., AFONINA O.M., IGNATOVA E.A., A. ABOLINA, T.V. AKATOVA, E. Z. BAISHEVA, L.V. BARDUNOV, E.A. BARYAKINA, O.A. BELKINA, A.G. BEZGODOV, M.A.BOYCHUK, V.YA. CHERDANTSEVA, I.V. CZERNYADJEVA, G.YA. DOROSHINA, A.P. DYACHENKO, V.E. FEDOSOV, I.L. GOLDBERG, E.I. IVANOVA, I. JUKONIENE, L. KANNUKENE, S.G. KAZANOVSKY, Z.KH. KHARZINOV, L.E. KURBATOVA, A.I.MAKSIMOV, U.K. MAMATKULOV, V. A. MANAKYAN, O.M. MASLOVSKY, M.G. NAPREENKO, T. N. OTNYUKOVA, L.YA. PARTYKA, O.YU. PISARENKO, N.N. POPOVA, G.F. RYKOVSKY, D.YA. TUBANOVA, G.V. ZHELEZNOVA, V.I. ZOLOTOV 2006 [2007]. Check-list of mosses of East Europe and North Asia. - Arctoa 15: 1-130.

IGNATOVA, E.A., M.S. IGNATOV, A.P. SEREGIN, T.V. AKATOVA \& N.A. KONSTANTINOVA 2005. Bryophyte flora of the projected Utrish Nature Reserve (North-West Caucasus, Russia). - Arctoa 14: 39-48.

[IGNATOVA, E.A., M.S. IGNATOV, V.G. ONIPCHENKO, V.I. ZOLOTOV \& N.A. KONSTANTINOVA] ИГНАТОВА Е.А., М.С. ИГНАТОВ, В.Г. ОНИПЧЕНКО, В.И. ЗОЛОТОВ, Н.А. КОНСТАНТИНОВА 2007. Флора мохообразных Тебердинского заповедника. - [Bryophyte flora of the Teberda Reserve] Флора и фауна заповедников. Москва [Flora i fauna zapovednikov. Moscow] 112: $86 \mathrm{pp}$.

[IGNATOVA, E.A. \& V.B. GOLUB] ИГНАТОВA Е.А., В.Б. ГОЛУБ 2006 [2007]. Новые находки мхов в Краснодарском крае. 1. - [New moss records in Krasnodar Territory] Arctoa 15: 256.

KHARZINOV, Z., N. PORTENIER, E. IGNATOVA, S. SHHAGAPSOEV \& M. IGNATOV 2004. Rare species and preliminary list of mosses of the Kabardino-Balkaria (Caucasus). - Arctoa 13: 33-40.

PUCHE, F. 2006. Tortella. - In: Flora Briophítica Ibérica. Vol. III (eds. Guerra, J., M.J. Cano \& R.M. Ros.). Universidad se Murcia, Sociedad Espańola de Briología, Murcia: 49-60.

[SAVICZ-LYUBITSKAYA, L.I. \& Z.N. SMIRNOVA] САВИЧ-ЛЮБИЦКАЯ Л.И., З.Н. СМИРНОВА 1970. Определитель листостебельных мхов ССCР. Верхоплодные мхи. - [Handbook of mosses of the USSR. The acrocarpous mosses] Л., Наука [Leningrad, Nauka], 822. 